Review

\title{
Current Methods for Extraction and Concentration of Foodborne Bacteria with Glycan-Coated Magnetic Nanoparticles: A Review
}

\author{
Emma Dester ${ }^{1,2}$ and Evangelyn Alocilja $1,2, *$ \\ 1 Nano-Biosensors Lab, Department of Biosystems and Agricultural Engineering, Michigan State University, \\ East Lansing, MI 48824, USA; desterem@msu.edu \\ 2 Global Alliance for Rapid Diagnostics, Michigan State University, East Lansing, MI 48824, USA \\ * Correspondence: alocilja@msu.edu; Tel.: +1-517-432-8672
}

Citation: Dester, E.; Alocilja, E. Current Methods for Extraction and

Concentration of Foodborne Bacteria with Glycan-Coated Magnetic

Nanoparticles: A Review. Biosensors 2022, 12, 112. https://doi.org/ 10.3390/bios12020112

Received: 8 January 2022

Accepted: 8 February 2022

Published: 11 February 2022

Publisher's Note: MDPI stays neutral with regard to jurisdictional claims in published maps and institutional affiliations.

Copyright: (C) 2022 by the authors. Licensee MDPI, Basel, Switzerland. This article is an open access article distributed under the terms and conditions of the Creative Commons Attribution (CC BY) license (https:// creativecommons.org/licenses/by/ $4.0 /)$.

\begin{abstract}
Rapid and accurate food pathogen detection is an essential step to preventing foodborne illnesses. Before detection, removal of bacteria from the food matrix and concentration to detectable levels are often essential steps. Although many reviews discuss rapid concentration methods for foodborne pathogens, the use of glycan-coated magnetic nanoparticles (MNPs) is often omitted. This review seeks to analyze the potential of this technique as a rapid and cost-effective solution for concentration of bacteria directly from foods. The primary focus is the mechanism of glycan-coated MNP binding, as well as its current applications in concentration of foodborne pathogens. First, a background on the synthesis, properties, and applications of MNPs is provided. Second, synthesis of glycan-coated particles and their theorized mechanism for bacterial adhesion is described. Existing research into extraction of bacteria directly from food matrices is also analyzed. Finally, glycan-coated MNPs are compared to the magnetic separation technique of immunomagnetic separation (IMS) in terms of cost, time, and other factors. At its current state, glycan-coated MNPs require more research to fully identify the mechanism, potential for optimization, and extraction capabilities directly in food matrices. However, current research indicates glycan-coated MNPs are an incredibly cost-effective method for rapid food pathogen extraction and concentration.
\end{abstract}

Keywords: foodborne illness; glycans; glycoprotein; food safety; foodborne pathogens

\section{Introduction}

Foodborne disease outbreaks are a significant cause of illness and death, with over 3000 preventable deaths occurring annually in the United States alone [1]. These outbreaks can also strain the healthcare system, with over 48 million illnesses and 128,000 hospitalizations in the U.S. each year [1]. On a global scale, the World Health Organization estimates that foodborne pathogens are responsible for 600 million illnesses and 420,000 deaths annually, with the burden especially high for children under the age of 5 and individuals in low-income regions [2]. Approximately $20 \%$ of the U.S. population has increased vulnerability, including elderly, immunocompromised, or pregnant individuals $[3,4]$. These illnesses lead to severe economic losses, with one study estimating a cost of USD 7 billion to the U.S. economy as a result of food safety incidents [5].

Certain bacteria are commonly associated with foodborne outbreaks, including Salmonella spp., Listeria monocytogenes, Bacillus cereus, Staphylococcus aureus, and Escherichia coli [6]. These bacteria often have specific foods they thrive in, including fresh fruits and vegetables. The absence of a cooking step during fresh produce preparation, which can often kill bacteria, further increases risk for the consumer [7]. With these fresh foods highly recommended for a healthy diet, ensuring produce safety is of the utmost importance [8]. Products of animal origin, including meats, milk, and dairy products, are also commonly implicated in foodborne outbreaks [6]. 
Traditional foodborne pathogen detection methods are typically enumerative, meaning they are based on the growth of viable cells in nutrient-rich medium [9]. Detection can then proceed through continued growth of the bacteria in selective media to identify the presence of target pathogens. These preferred methods, outlined in the FDA's Bacteriological Analytical Manual (BAM), are widely used but can take several days to produce conclusive results and incur high labor costs [10]. In recent years, rapid detection methods have been explored to remedy the time-consuming and costly nature of traditional enumerative methods. Nucleic acid-based quantitative analysis with real-time polymerase chain reaction (rt-PCR) can dramatically reduce detection time with high sensitivity [11]. However, high equipment costs are a significant limitation for some applications [12]. Biosensors, which convert biological, chemical, or biochemical elements into measurable signals, have also demonstrated success for rapid and cost-effective food pathogen detection [13].

Regardless of the detection method employed, concentration of bacteria from the food matrix is typically an essential step. The aforementioned conventional microbiological protocols often require overnight culturing of the bacteria (24-48 h) in selective media for pre-enrichment, increasing target bacterial concentration to detectable levels and minimizing interfering microorganisms [10]. For rapid extraction and detection methods, complex food matrices often introduce new challenges. Food macromolecules, including fats, glycogen, and other components, can block specific interactions between target molecules and receptors in many biosensors, as well as PCR-based detection [14,15]. Thus, there is an immense need for rapid and cost-effective techniques that concentrate target bacteria while effectively removing them from the interfering food matrix. Rapid detection methods such as biosensors and PCR often employ techniques such as centrifugation [16,17], filtration [17], dielectrophoresis [18], metal hydroxides [19,20], and magnetic nanoparticles (MNPs) [21-24] to attempt to fulfill these needs without overnight culturing (Table 1).

However, physical methods such as centrifugation and filtration often encounter challenges when separating bacteria from food matrices. Centrifugation, which separates particles based on density, can often fail to capture cells adhering to food particles while also capturing dead bacteria [25-27]. Filtration also encounters challenges in certain foods, leading to filter clogging and ineffective separation of bacteria [28,29]. Both methods lack specificity and cannot target specific bacteria species [26,30]. Similarly, metal hydroxides are non-specific and often have high limits of detection, or the assays require incubation before subsequent pathogen detection $[19,20,30,31]$. Some chemical methods allow for specificity and debris removal, such as dielectrophoresis [18,32-34]. However, the limit of detection for concentrated cells extracted from foods is often high, suggesting low capture efficiency through this method [18]. Thus, the search for a rapid, cost-effective, and efficient method of bacteria concentration from food matrices is still ongoing.

MNPs in particular have attracted attention for foodborne pathogen concentration due to their low cost, unique properties, and functionalization capabilities [35-37]. Antibodyfunctionalized MNPs, for example, have demonstrated specific and rapid concentration capabilities through immunomagnetic separation (IMS) [21,22]. Meanwhile, glycan-coated MNPs show promise as a lower-cost alternative for rapid food pathogen extraction and concentration through carbohydrate-lectin interactions [23,24]. In addition, application of glycan-coated MNPs in combination with biosensors is a cost-effective and rapid food pathogen detection method [38,39]. However, this methodology is often not included in conventional reviews of foodborne pathogen concentration methods $[9,11,30,40]$. This review seeks to summarize and analyze recent advancements and applications of glycancoated MNPs for bacterial concentration from complex food matrices. 
Table 1. Overview of existing methods for rapid bacteria concentration from food matrices.

\begin{tabular}{|c|c|c|c|c|}
\hline Method & Description & Advantages & Disadvantages & References \\
\hline Centrifugation & $\begin{array}{l}\text { Bacteria concentrated } \\
\text { by centrifugation and } \\
\text { food solution can } \\
\text { be removed }\end{array}$ & $\begin{array}{l}\text { Can concentrate from } \\
\text { large sample volume, } \\
5-30 \text { min assay }\end{array}$ & $\begin{array}{l}\text { Not selective, loss of } \\
\text { bacteria adhered to food } \\
\text { particles, captures } \\
\text { dead cells }\end{array}$ & {$[19,20,25-27]$} \\
\hline Filtration & $\begin{array}{l}\text { Samples passed } \\
\text { through filters with } \\
\text { various pore sizes, } \\
\text { allowing bacteria to } \\
\text { pass while eliminating } \\
\text { food particles }\end{array}$ & $\begin{array}{l}\text { 1-10 min assay, remove } \\
\text { inhibitors in } \\
\text { food matrix }\end{array}$ & $\begin{array}{l}\text { Filter clogging is common, } \\
\text { non-target bacteria } \\
\text { often concentrated }\end{array}$ & {$[17,28,29]$} \\
\hline Metal hydroxides & $\begin{array}{l}\text { Immobilization of } \\
\text { titanium or zirconium } \\
\text { hydroxides to bacteria } \\
\text { through chelation } \\
\text { followed } \\
\text { by centrifugation }\end{array}$ & $\begin{array}{l}\text { Cost-effective, } \\
\text { maintains cell viability }\end{array}$ & $\begin{array}{l}\text { Centrifuge required, needs } \\
\text { enrichment step, limited } \\
\text { research in foods }\end{array}$ & {$[19,20,30,31]$} \\
\hline Dielectrophoresis & $\begin{array}{l}\text { Nonuniform electric } \\
\text { field used to } \\
\text { manipulate } \\
\text { bacterial cells }\end{array}$ & $\begin{array}{l}\text { Option for specificity, } \\
\text { maintains cell viability }\end{array}$ & $\begin{array}{l}\text { Potentially low } \\
\text { capture in foods }\end{array}$ & {$[18,32-34]$} \\
\hline $\begin{array}{c}\text { Glycan-coated MNP } \\
\text { separation }\end{array}$ & $\begin{array}{l}\text { Glycans on MNPs } \\
\text { electrostatically bind, } \\
\text { extract, and } \\
\text { concentrate bacteria }\end{array}$ & $\begin{array}{l}\text { Cost-effective, option } \\
\text { for specificity }\end{array}$ & $\begin{array}{l}\text { May bind to food particles, } \\
\text { limited research in foods }\end{array}$ & {$[24,38-42]$} \\
\hline $\begin{array}{l}\text { Immunomagnetic } \\
\text { separation }\end{array}$ & $\begin{array}{l}\text { MNPs coated with } \\
\text { specific antibodies bind, } \\
\text { extract, and concentrate } \\
\text { target bacteria }\end{array}$ & $\begin{array}{l}\text { High specificity and } \\
\text { capture efficiency }\end{array}$ & $\begin{array}{l}\text { Costly synthesis and } \\
\text { storage, not standardized }\end{array}$ & {$[14,21,22,43]$} \\
\hline
\end{tabular}

\section{Magnetic Nanoparticles}

Magnetic nanoparticles have attracted attention in recent years due to their unique properties. Nanoparticles, including MNPs, typically have a diameter ranging from 1-100 nm [44]. On this scale, particles can exhibit physicochemical properties disparate from those on a macro scale, including strength, magnetism, chemical reactivity, and optical properties, among many others [45]. In particular, the low cost and magnetic properties of MNPs have led to increased interest in their widespread use [35-37]. Due to these unique characteristics, MNPs have been applied to various roles in health, science, and technological innovation [46-49].

\subsection{Synthesis and Characteristics}

MNPs can be composed of a variety of materials including pure metals $(\mathrm{Fe}, \mathrm{Co}, \mathrm{Ti}$, $\mathrm{Ni})$, metal oxides, ferrites, and metal alloys. Iron oxides such as magnetite $\left(\mathrm{Fe}_{3} \mathrm{O}_{4}\right)$ and maghemite $\left(\mathrm{Fe}_{2} \mathrm{O}_{3}\right)$ are some of the most common MNP core materials [50,51]. Several synthesis methods for these nanoparticles include coprecipitation, high-temperature thermal decomposition, hydrothermal processes, and microemulsion, among many others [48,51]. An excellent review of these synthesis methods and materials, as well as their many biomedical applications, is detailed by Cardoso et al. [51].

One significant advantage of MNPs for many applications is their superparamagnetic properties, meaning they do not have a net magnetization and do not aggregate without an external magnet [24]. Superparamagnetism typically emerges at a particle size of $10-20 \mathrm{~nm}$ [52]. As a result, magnetic nanoparticles of this size quickly disperse in liquids but can still be magnetized and manipulated by an external magnetic field [24]. Thus, they are excellent tools for efficient capture of cells, proteins, and biomolecules. MNPs can easily 
be suspended in solutions for bacterial capture before separation from the supernatant using a magnet $[53,54]$.

Another attractive aspect of MNPs is their high surface-area-to-volume ratio. The high adsorption capacity of this increased surface area leads to potentially high capture efficiency for the target cells [45]. In addition, MNPs are typically much smaller than bacterial cells, leading to multiple particles often attaching to a single cell. This behavior has been shown through microscopic imaging in multiple studies [24,42]. Similar TEM and confocal laser microscope images have been captured in the Nano-Biosensors Laboratory, pictured in Figure 1. This adhesion of multiple MNPs to a single cell may increase the probability of bacterial capture.

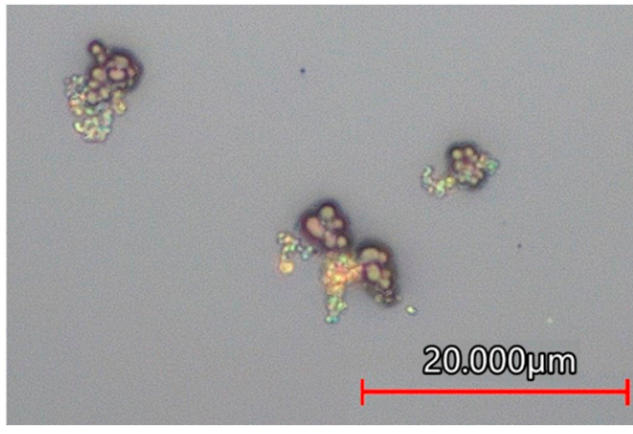

(a)

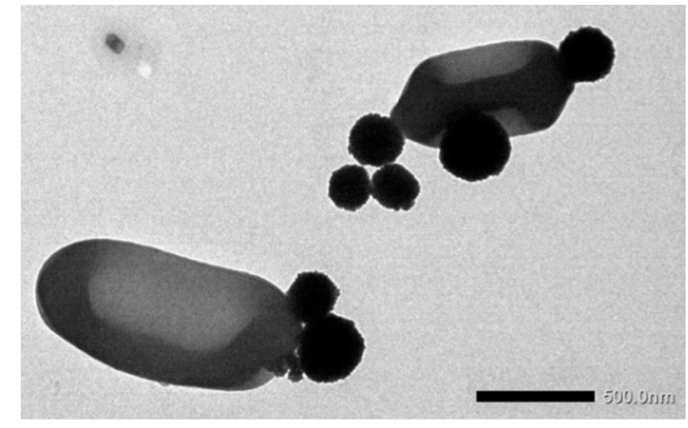

(b)

Figure 1. (a) Confocal laser microscope image of multiple MNPs bound to clusters of S. aureus cells; (b) TEM image of multiple MNPs bound to L. monocytogenes cells.

\subsection{Surface Modification}

Various natural polymer materials or alkene monomer copolymers are used to "coat" the nanoparticles for stabilization, modification, or the introduction of active groups [43]. Since uncoated metallic nanoparticles are chemically active and easily oxidized in air, protection and stabilization methods are often necessary to maintain their magnetic properties and prevent particle aggregation [54]. This is typically accomplished by a "core-shell" formation through physical adsorption or covalent bonding of desired compounds to MNPs [55]. While the magnetic properties of MNPs are determined by the metallic core, surface coatings can be used to control MNP selectivity and other properties specific to various applications. Some common coatings include surfactant molecules, ligands, silica, and colloidal gold, each with their own applications and unique characteristics $[44,49,55]$. A comprehensive review of MNP coating methodologies and their biomedical applications is provided by Pryazhnikov et al. [55].

\subsection{Applications of MNPs in Food Pathogen Extraction}

In addition to the unique properties outlined previously, MNPs show immense promise in food pathogen detection due to their rapid and low-cost capabilities for the separation of bacteria from complex matrices without the need for centrifugation or filtration [45]. Although the functionalization and surface modification of MNPs for food pathogen extraction vary widely, most studies utilize the same basic procedure for bacterial extraction [24,39,56-58]. As shown in Figure 2, MNPs are introduced to a liquified food sample that is naturally or artificially contaminated with one or more bacterial species. After MNPs have been evenly dispersed in the liquid, the sample is incubated from one minute to up to an hour to allow the MNPs to adhere to the target cells. After incubation, an external magnet is applied, and the supernatant is removed. Samples can be resuspended in a lower sample volume for bacterial concentration, sometimes after multiple washing steps to remove any remaining food matrix components. Various detection methods using biosensors or PCR can then be implemented [39,56-58]. 


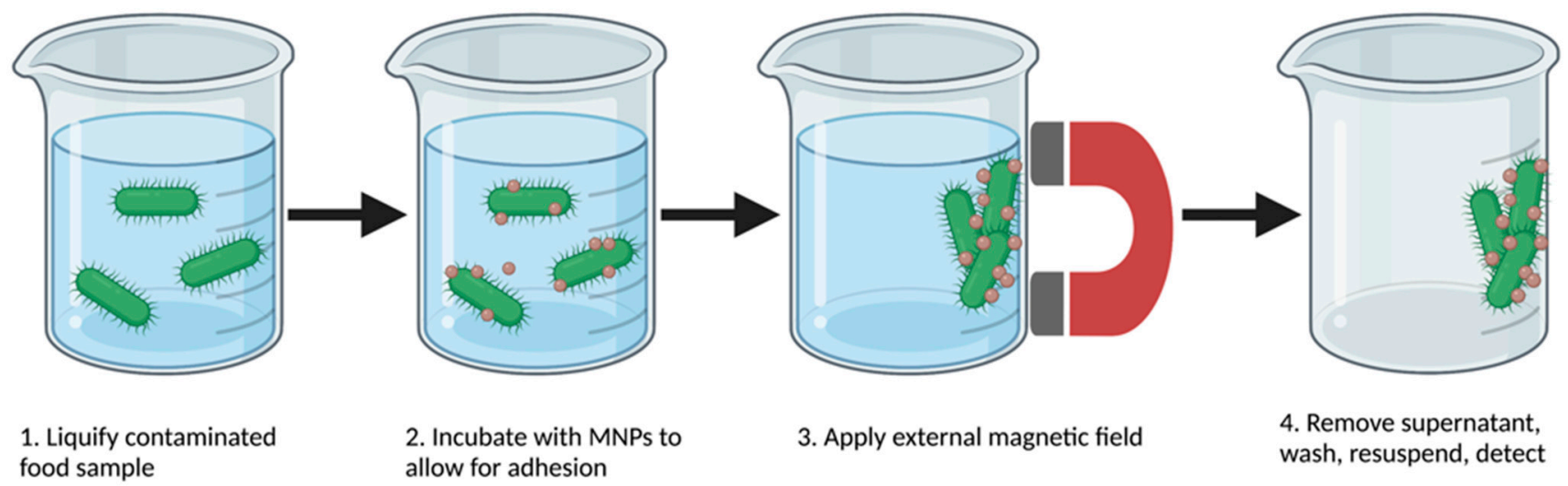

Figure 2. Overview of magnetic separation of bacteria from food samples.

MNPs adhere to bacterial cells through a wide variety of mechanisms, often depending on their surface coating and functionalization. Common mechanisms include antigenantibody binding $[14,21,58,59]$, carbohydrate-lectin interactions $[24,38,39,42,60]$, general electrostatic interactions [20,23,39], and covalent binding [61,62]. After concentration, these concentrated MNP/bacteria samples can be used in many detection methods, including PCR, cyclic voltammetry, enzyme-based assays, and other biosensors. The current state of standard magnetic separation techniques for food pathogen applications is outlined in the following sections.

\section{Carbohydrate Functionalized (Glycan-Coated) Magnetic Separation}

\subsection{Mechanism of Glycan-Coated MNP Bacterial Adhesion}

Glycans (complex carbohydrates) play an essential role in many cellular mechanisms, including cell-cell interactions [63]. Bacterial infection in particular is often initiated by interactions between bacterial surface proteins (e.g., lectins) and tissue carbohydrates [64], [41]. For instance, H. pylori, which causes chronic gastritis, often contains adhesins (lectins) on its cell surface that recognize host cell glycans to initiate infection [65]. Glycan-protein interactions can also play a role in the formation of bacterial biofilms through interactions between neighboring cells [66]. These interactions are non-covalent and electrostatic in nature, often consisting of van der Waals interactions as well as hydrogen bonds between hydroxyl and amino groups present on the carbohydrate and microbial protein surface $[67,68]$.

In recent years, researchers have explored utilizing these protein-glycan interactions to extract and detect bacterial cells. Lectins have broad specificities for complex carbohydrates [68]. Thus, magnetic nanoparticles coated with glycans can bind to various bacteria cells through non-covalent electrostatic interactions with protein residues on the bacteria surface, effectively mimicking the role of cell surface glycans $[53,63]$. Due to the superparamagnetic properties of the MNPs, the MNP-bacteria complexes can then be manipulated by an external magnetic field, allowing for rapid extraction of the bacteria [23].

Nonspecific capture of bacterial cells may also be enhanced by the positively charged nature of some glycan-coated MNPs compared to the negatively charged bacteria cell membranes. The isoelectric points of both Gram-positive and Gram-negative bacteria range from 4.15 to 1.75 , resulting in a net negative charge under physiological conditions $[69,70]$. This is due to negative cell wall components such as teichoic acids and lipopolysaccharides [71]. Thus, MNPs with net positively charged surface coatings may promote bacterial attraction and adhesion through electrostatic interactions with these negatively charged regions. Since glycans and proteins must be in close proximity to achieve adhesion, these general electrostatic interactions can promote bacterial capture by MNPs [72]. These electrostatic interactions are theorized to play a role in many glycan-coated MNP applications and are often improved through the addition of amino acids to the MNP coating [23,38,39]. 
Thus, glycan-coated MNP binding to bacteria in a fluid matrix is hypothesized to be facilitated by a combination of forces, as summarized in Figure 3. Brownian motion, the random and uncontrolled movement of particles in a fluid, can initially facilitate movement that randomly brings cells in close proximity to glycan-coated MNPs [23,73]. If the coated nanoparticles have a net positive charge, electrostatic forces between MNPs and negatively charged cell membranes can also draw bacteria towards the MNPs [23,38,39,70]. Once in close proximity, due to random motion or electrostatic forces, the bacterium can adhere to the glycan surface of MNPs through non-covalent carbohydrate-protein binding, including van der Waals forces and hydrogen bonds $[67,68]$. A positively charged glycan coating may improve this adhesion by reducing electrostatic repulsion [23].

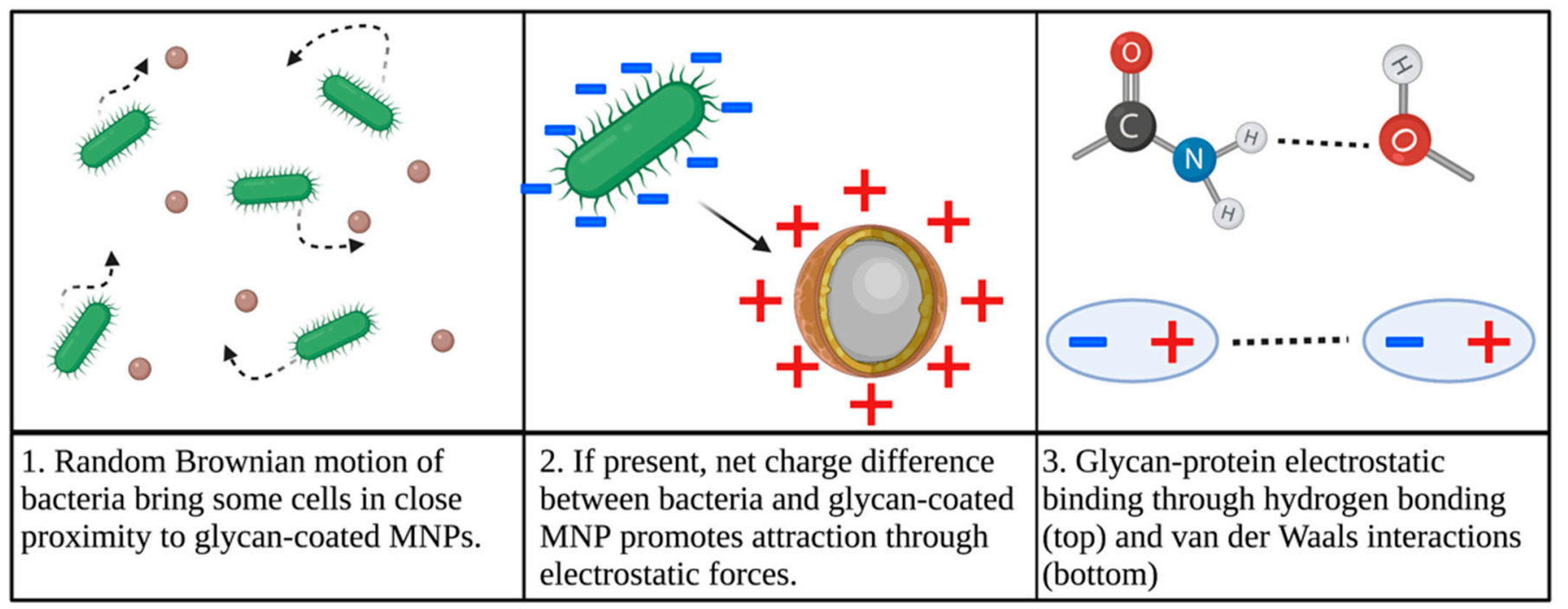

Figure 3. Overview of hypothesized mechanism for glycan-coated MNP binding to bacteria.

The general nature of these carbohydrate-protein interactions can best be illustrated through specific examples. Chitosan, for instance, is a cationic polysaccharide derived from chitin; due to its biodegradability and biocompatibility, along with other biological and physicochemical properties, it has become a favorable glycan coating for MNPs [36,74,75]. Chitosan has both hydroxyl $(-\mathrm{OH})$ and amino $\left(-\mathrm{NH}_{2}\right)$ groups. At a low $\mathrm{pH}$, chitosan becomes positively charged through the protonation of these amino groups [37]. Thus, the chitosan-coated MNP will have a net positive charge at this $\mathrm{pH}$, drawing the particles towards the negatively charged bacteria cells through generalized electrostatic interactions. Once the bacteria and MNPs are in close proximity, adhesion between chitosan and glycanbinding proteins on the bacterial surface can occur through non-covalent interactions. At a higher $\mathrm{pH}$, however, binding may still occur. The negatively charged hydroxyl groups on chitosan can form hydrogen bonding interactions with positively charged pockets of the cell membrane, allowing for MNP-bacteria adhesion [24].

\subsection{Glycan-Coated MNP Synthesis}

As reviewed by Fratila et al. [76], carbohydrate coating of MNPs can be achieved through either an in situ process during MNP synthesis or as a post-synthetic functionalization step. For in situ methods, ligand adsorption onto the MNP surface is accomplished through MNP synthesis in the presence of carbohydrates. Post-synthetic methods entail the introduction of functionalized carbohydrates to the surface of the MNPs by ligand exchange, covalent linking, or non-covalent functionalization [76]. A wide variety of glycans have been employed as MNP coatings for attachment to bacteria. Some examples include mannose, galactose, fucose, and chitosan $[23,42,65]$. Glycan-coated MNPs may be further modified by adding other materials, such as amino acids, which could potentially be used to increase the positive charge of the MNP coating and promote bacterial adhesion $[38,39]$. 


\subsection{Applications of Glycan-Coated MNPs}

Extraction and concentration of bacteria using glycan-coated MNPs has been employed for a variety of applications outside of foodborne pathogens. Briceno et al. [23] utilized chitosan-coated iron oxide nanoparticles to concentrate Mycobacterium tuberculosis in sputum samples before detection with a colorimetric biosensing assay. The magnetically activated cell enrichment allowed for rapid detection of the bacteria at low concentrations in only $20 \mathrm{~min}$. In addition to having $100 \%$ sensitivity and $99.7 \%$ specificity compared to the gold standard culture method, it was also a more cost-effective alternative at only USD 0.50 /test [23]. Glycan-coated nanoparticles have also been employed to capture bacteria such as Helicobacter pylori [65] and Pseudomonas aeruginosa [77], among many others.

Glycan-coated MNPs have also been employed for extraction of pathogens directly from food matrices. One study utilized two unspecified forms of glycan-coated MNPs, referred to as F\#1 and F\#2, to extract Salmonella Enteritidis, Escherichia coli O157:H7, and Bacillus cereus from milk samples [24]. Magnetic nanoparticles were first added to $25 \mathrm{~mL}$ milk samples, followed by inoculation with concentrations of bacteria ranging from 2.9-4.5 $\log$ CFU $/ \mathrm{mL}$. After $10 \mathrm{~min}$, the samples were mixed and magnetically separated before removal of the matrix and resuspension in $1 \mathrm{~mL}$ milk. Capture efficiencies ranged from $73-90 \%$ on a log basis, with no significant relationship between MNP type and milk or bacteria type. Notably, the researchers also tested the simultaneous extraction of all three bacteria. Capture efficiencies for each bacteria type in the mixture were similar to that of each bacteria species when extracted individually. Thus, this method was effective for the nonspecific extraction of multiple food pathogens [24].

The same author also successfully extracted Salmonella Enteritidis, Escherichia coli O157:H7, and Listeria monocytogenes from homogenized egg, vitamin D milk, and apple cider using cysteine-glycan coated iron oxide MNPs (F\#2) [38]. In this study, the MNPs were affixed to plastic strips and inserted into $25 \mathrm{~mL}$ of the sample matrix instead of directly suspended in the matrix. The MNP strips were incubated in the matrix for $10 \mathrm{~min}$ before removal and subsequent pathogen detection using cyclic voltammetry. Although capture efficiency data was not available, this method distinguished between samples and negative controls with 95\% confidence [38].

Another author created starch magnetic nanoparticles by co-crystallizing short chain glucans (SCG) with dextran-coated iron oxide nanoparticles [39]. The resulting glycanMNPs were further modified through functionalization with the positively charged amino acid lysine. The authors used these strongly positive glycan-MNPs to electrostatically adhere to and extract E. coli O157:H7 cells from $10 \mathrm{~mL}$ samples of liquified sausage. The MNPs successfully adhered to and extracted $90 \%$ of the bacteria cells in only 10 min at concentrations from $10^{1}$ to $10^{5} \mathrm{CFU} / \mathrm{mL}$ in pure bacteria samples. In sausage samples, extraction and concentration combined with a colorimetric biosensor showed the $95 \%$ confidence limit of detection to be $30.8 \mathrm{CFU} / \mathrm{mL}$. The nonspecific extraction method and specific biosensor detection method led to successful test results within food matrices [39].

Although glycan-coated MNPs can be used for nonspecific capture of bacteria, selectivity can also be improved by utilizing specific carbohydrate epitopes. For instance, biotinylated oligosaccharides immobilized to streptavidin-coated magnetic beads have been used to selectively capture E. coli strains with the pap pilus genotype [60]. After a 1-h incubation with the MNPs, bacteria samples suspended in phosphate-buffered saline solution (PBS) were magnetically separated for $5 \mathrm{~min}$ before resuspension. The assay had high selectivity for the three pap-containing uropathogenic (UPEC) strains when compared to three non-pathogenic or enterohemorrhagic E. coli strains. Capture efficiency was quantified through a BacTiter-Glo assay substrate. For the three target $E$. coli strains, capture efficiency ranged from $17-34 \%$ [60].

One primary advantage of carbohydrate functionalized MNPs is their low cost. One study, for instance, noted that using glycan-coated MNPs instead of a similar antibodybased assay reduced testing cost from USD 0.40 to USD 0.10 per assay [24]. In addition, glycan-coated MNPs do not require special handling and have a long shelf life at room 
temperature, further reducing overall expenses when compared to IMS [41]. The MNPs also typically require short incubation times (5-10 $\mathrm{min}$ ) with the target bacteria [24,42]. Thus, the rapid and cost-effective nature of glycan-coated MNPs show promise for accessible extraction of foodborne bacteria without expensive equipment or long incubation times.

Despite its economical and efficient nature, this non-specific interaction may lead to complications in complex food matrices. Furthermore, due to their similar chemistries, carbohydrates present in the food may also electrostatically bind to the glycans on the MNPs [38]. Depending on the subsequent detection method employed, this may lead to limitations with pathogen detection. At its current state, the main drawback of this method for extraction of bacteria from food is the limited research (Table 2). Although other researchers have successfully extracted foodborne pathogens such as $E$. coli from pure cultures using glycan-coated MNPs [42,60], the previous papers by Matta and Alocilja [24] and You et al. [39] were the only research found referring to extraction of bacteria directly from a food matrix. Further study is required to determine the success of this method for food pathogen extraction.

Table 2. Glycan-coated MNPs for extraction and concentration of foodborne pathogens.

\begin{tabular}{|c|c|c|c|c|c|}
\hline Coating & Bacteria & Matrix & Capture & Detection Method & Source \\
\hline $\begin{array}{c}\text { Glycan } \\
\text { (not specified), } \\
\text { cysteine-glycan }\end{array}$ & $\begin{array}{l}\text { S. enteritidis, E. coli } \\
\text { O157:H7, B. cereus }\end{array}$ & $\begin{array}{l}\text { Milk (vitamin D, } \\
\text { reduced fat, fat-free) }\end{array}$ & $73-90 \%$ * & $\mathrm{N} / \mathrm{A}$ & {$[24]$} \\
\hline Cysteine-glycan & $\begin{array}{l}\text { S. enteritidis, E. coli O157:H7, } \\
\text { L. monocytogenes }\end{array}$ & $\begin{array}{l}\text { Homogenized egg, } \\
\text { vitamin D milk, } \\
\text { apple cider }\end{array}$ & $\mathrm{N} / \mathrm{A}$ & Cyclic voltammetry & {$[38]$} \\
\hline Lysine-SCGs & E. coli O157:H7 & Sausage & $>90 \% * *$ & $\begin{array}{l}\text { Colorimetric } \\
\text { biosensor }\end{array}$ & {$[39]$} \\
\hline $\begin{array}{c}\text { Biotinylated } \\
\text { oligosaccharides }\end{array}$ & E. coli (UPEC) & PBS & $17-34 \%$ & $\mathrm{~N} / \mathrm{A}$ & {$[60]$} \\
\hline $\begin{array}{l}\text { Mannose } \\
\text { Galactose }\end{array}$ & E. coli strains (3) & PBS & $\begin{array}{l}10-65 \% \\
15-75 \%\end{array}$ & BacTiter-Glo assay & {$[42]$} \\
\hline
\end{tabular}
food samples.

\section{Immunomagnetic Separation Versus Glycan-Coated MNP Separation}

One of the most well-known and widely researched types of magnetic separation for foodborne pathogen extraction is immunomagnetic separation (IMS) [43]. Thus, a fuller understanding of glycan-coated MNP assays can be achieved by comparing and differentiating this method from IMS. Instead of glycans, IMS utilizes antibodies immobilized to MNPs to extract and concentrate target bacteria [43]. The differences between glycan-coated MNP extraction, however, are not limited to the surface coating. A summary of the key characteristics compared in this section are shown in Table 3.

Table 3. Immunomagnetic separation versus glycan-coated MNPs.

\begin{tabular}{ccc}
\hline & Immunomagnetic Separation & Glycan-Coated MNPs \\
\hline Binding mechanism & $\begin{array}{c}\text { Antibodies on MNP surface bind to } \\
\text { antigens on cell surface }\end{array}$ & $\begin{array}{c}\text { Glycans on MNP surface bind to proteins } \\
\text { on bacteria surface }\end{array}$ \\
\hline Specificity & Very specific & $\begin{array}{c}\text { Typically nonspecific, but specific glycans } \\
\text { can be designed }\end{array}$ \\
\hline Experimental Cost/Time & Rapid, relatively high cost & Rapid, low cost (25\% of cost for IMS) \\
\hline Storage & Antibodies require refrigeration & Room temperature \\
\hline Current research & Well-researched and regularly used with \\
PCR and biosensors & Limited studies in food matrices
\end{tabular}




\subsection{Binding Mechanism}

The first step of IMS is to capture the bacteria, which is facilitated by the binding of a specific antibody to the target bacteria. Antibodies are a three-lobed structure composed of two light chains and two heavy chains. Two of the lobes have fragment antigen binding (Fab) regions that are responsible for the specificity of the antibody [78]. These Fab regions adhere to antigens on the target cell surface through non-covalent electrostatic interactions of salt bridges and hydrogen bonds [79]. Long-range electrostatic forces can assist in bringing the antibodies towards the docking site [79].

Glycan-coated MNPs also adhere to bacteria through non-covalent electrostatic interactions, as discussed in detail in Section 3.1. In addition, the hypothesized long-range nonspecific electrostatic interactions are similar to those described for IMS. One important difference lies in the bond strength, with a single glycan-protein interaction having low affinity [72]. This can typically be overcome through the binding of multiple MNPs to a single bacterium [60]. Specificity of the two binding methods can also differ, as discussed in the following section.

\subsection{Specificity}

One of the most notable advantages of IMS is its high specificity; the use of antibodies allows for specific extraction of target bacteria and exclusion of natural microflora [21] Specificity can be controlled through factors such as incubation time with the MNPs [80] and the specificity of the antibody itself [79]. The separation process can also remove PCR inhibitors, reducing purification steps required before detection [15].

Unlike IMS, current food pathogen extraction research using glycan-coated MNPs typically focuses on nonspecific concentration of cells [24,38,39]. However, some research has developed glycans specific to certain bacterial species [60]. Further, other studies have noted significantly different capture efficiencies between bacteria strains [42]. This versatility demonstrates the potential for glycan-coated MNPs to be applied in a variety of food pathogen detection settings, whether the target organism is known or unknown.

\subsection{Experimental Time and Cost}

IMS is rapid in comparison to many other assays, with incubation time (the time MNPs are exposed to the sample before magnetic separation) typically varying from $10-45 \min [21,43,59,81,82]$. Most sources successfully implemented the entire extraction procedure in under $2-3 \mathrm{~h}[14,58,59,81]$. However, immunomagnetic separation is also costly compared to conventional methods [43]. Although this method could become more inexpensive through automation techniques that are currently being explored [14], the current lack of standardization does not permit its widespread implementation to detect foodborne pathogens at a low cost.

Glycan-coated MNP extraction is similar to IMS in its rapidity and may even shorten extraction times. Although limited data is available, currently published literature on foodborne pathogen extraction indicates only $5-10 \mathrm{~min}$ of incubation is necessary for glycanbacteria binding to occur [38,39,42]. In addition, glycan-coated MNPs are significantly more cost-effective than immunomagnetic particles. As mentioned previously, one study conducted glycan-coated MNP extraction with $25 \%$ of the cost of a similar antibody-based assay [24].

\subsection{Storage}

After synthesis, the antibody-MNP complexes used in IMS must typically be stored at $4{ }^{\circ} \mathrm{C}$ until use $[58,82,83]$. Meanwhile, glycan-coated MNPs do not require special handling and have a long shelf life at room temperature [41]. For instance, one study examined the stability of iron oxide MNPs coated in either alginate or chitosan and suspended in buffer solutions [36]. The researchers found no flocculation, settling, or changes in hydrodynamic size after 6 months in room-temperature conditions. These simple storage measures further reduce overall expenses when compared to IMS. In addition, the simple storage 
conditions emphasize the feasibility of utilizing glycan-coated MNPs in low-resource settings, increasing the accessibility of rapid foodborne pathogen extraction.

\subsection{Current Research}

Immunomagnetic capture has been employed with a variety of bacteria and food matrices for detection using real-time or quantitative PCR. For instance, one author devised an IMS procedure for extracting strains of L. monocytogenes from inoculated soybean sprouts [59]. After a 20-min incubation with IM beads, the recovery was 1.16-1.96 logs below the initial concentration (approximately $1-10 \%$ recovery). With rt-PCR, this method was found to have a LOD of $4.4 \log \mathrm{CFU} / \mathrm{g}$ [59]. Immunomagnetic separation of target bacteria from food has been employed with a variety of other detection methods with high sensitivity. One recent study, for example, was capable of detecting E. coli from fish muscle at concentrations as low as $10 \mathrm{CFU} / \mathrm{mL}$ using IMS and mass spectrometry [84]. Other detection methods implementing IMS for bacteria concentration include fluorescence methods [83], surface plasmon resonance [57,85], microfluidics [86], and other biosensors [22,87].

Standardization and automation of IMS has been tested. One study developed an automated IMS platform to extract and concentrate target bacteria using milk inoculated with E. coli O157:H7 [14]. After 60 min of sample pre-enrichment at $37^{\circ} \mathrm{C}$, immunomagnetic beads were added and incubated for $30 \mathrm{~min}$. Results through plating of treated and untreated samples produced a capture efficiency of $20 \%$; due to the initial 250 sample volume being reduced to $1 \mathrm{~mL}$, their system led to a 100-fold concentration of the target bacteria. The entire extraction procedure could be completed in two hours [14]. This automated system was later tested alongside an enzyme-based colorimetric assay for bacteria detection [88]. With IMS, the assay could detect E. coli O157 in initial milk samples at concentrations as low as $3 \times 10^{2} \mathrm{CFU} / \mathrm{mL}$ [88].

Although results are promising, current glycan-coated MNP research is more limited in comparison. However, the extraction method has been paired with cyclic voltammetry for successful pathogen detection [38]. Another study using poly-l-lysine-coated starch MNPs was able to detect $E$. coli $\mathrm{O} 157$ in sausage using a paper-based colorimetric biosensor with a limit of detection of $30.8 \mathrm{CFU} / \mathrm{mL}$ [39]. No current literature was found describing automation of this foodborne pathogen extraction method. However, due to their similar methodologies, an automated immunomagnetic separation system could easily be adapted for use with glycan-coated MNPs.

\section{Discussion}

At its current state, new methods for bacterial capture and concentration from foodborne pathogens have demonstrated several key advancements over the traditional culture method. New techniques with dielectrophoresis, centrifugation, filtration, and MNPs have been used to rapidly concentrate bacteria from foods to a detectable level without the need for cultural enrichment, often with assay times under $1 \mathrm{~h}$ in duration. In addition, the cost-effectiveness of many of these methods further enhances their applicability in food pathogen detection. However, physical methods such as centrifugation and filtration still show serious disadvantages in their lack of specificity and challenges with food matrix removal. Common chemical methods face challenges as well. Metal hydroxides lack specificity, and current methods in food matrices typically still require cultural enrichment before detection. Dielectrophoresis has demonstrated detection capabilities without cultural enrichment, but there is often a high limit of detection when only this concentration method is employed.

MNPs can provide cost-effective and rapid alternatives to many traditional food pathogen extraction methods while alleviating some of these concerns. Some applications, such as immunomagnetic separation, have been used in several assays in conjunction with PCR and biosensing techniques to rapidly detect bacterial concentrations in foods. Existing studies with glycan-coated MNPs have produced similar results, with the added 
advantage of reduced assay cost. In addition, the combination of lower-cost materials and room-temperature storage conditions enhances its accessibility and applicability.

However, the lack of standardization of MNPs hinders its current ability to be utilized as a food pathogen extraction method. Although immunomagnetic separation is the most researched technique, it still lacks standardization and automation that would allow for its widespread use. Meanwhile, there are few published works on direct bacteria extraction from food matrices using glycan-coated MNPs, and the composition of glycan coatings widely vary between studies. Regardless, MNPs show promise in a variety of fields in part due to their immense versatility and variability. The high capture efficiencies exhibited in multiple methods, as well as low limits of detection when combined with various biosensors and other detection methods, demonstrate their future potential.

\section{Conclusions and Future Perspectives}

Globally, foodborne pathogens are currently responsible for millions of illnesses and thousands of deaths each year. Thus, rapid and accurate detection methods are essential for reducing this strain on global health and the global economy. Although rapid detection methods are being developed to replace traditional culture-based methods, bacterial capture and concentration is still an important step for food pathogen detection. This review extensively outlined glycan-coated MNP methods for bacteria concentration in foods, which have shown promise for rapid detection of foodborne pathogens.

Although many reviews recount the applications of IMS, the application of other types of MNPs for foodborne pathogen concentration, such as glycan-coated MNPs, has not generally been discussed. Furthermore, reviews of glycan-coated MNPs rarely focus on their applications for foodborne pathogens. The qualities of these MNPs in particular, such as their low cost and room-temperature storage conditions, demonstrate the importance of including these techniques as a potential foodborne pathogen concentration method. Although current research in this application is limited, existing results are promising. Further, the mechanism of glycan-coated MNP binding to bacterial cells is rarely reviewed thoroughly in the literature. This review sought to compile sources on this binding mechanism to synthesize a comprehensive description of this mechanism and its specific applications in food. In future research, glycan-coated MNP applications in direct food pathogen bacteria extraction can be optimized, and bacterial adhesion mechanisms can be further elucidated. With these developments, MNPs have the potential to revolutionize current food pathogen detection methods to eliminate overnight incubation periods, reduce detection costs, and save lives.

Author Contributions: Conceptualization, E.A. and E.D.; validation, E.A.; formal analysis, E.D.; investigation, E.D.; resources, E.A.; writing—original draft preparation, E.D.; writing-review and editing, E.A.; visualization, E.D.; supervision, E.A.; funding acquisition, E.A. All authors have read and agreed to the published version of the manuscript.

Funding: This research was funded by the Targeted Support Grant for Technology Development (TSGTD), Michigan State University Foundation. This work was also supported by the USDA National Institute of Food and Agriculture, Hatch project 1012975.

Institutional Review Board Statement: Not applicable.

Informed Consent Statement: Not applicable.

Data Availability Statement: Not applicable.

Acknowledgments: Figures 2 and 3 were created with Biorender.com (20 December 2021).

Conflicts of Interest: The authors declare no conflict of interest. 


\section{References}

1. Scharff, R.L. Economic burden from health losses due to foodborne illness in the United States. J. Food Prot. 2012, 75, 123-131. [CrossRef] [PubMed]

2. World Health Organization. WHO Estimates of the Global Burden of Foodborne Diseases: Foodborne Disease Burden Epidemiology Reference Group 2007-2015. 2015. Available online: https:/ /apps.who.int/iris/handle/10665/199350 (accessed on 12 November 2021).

3. Lund, B.M. Microbiological Food Safety for Vulnerable People. Int. J. Environ. Res. Public Health 2015, 12, 10117. [CrossRef] [PubMed]

4. Lund, B.M.; O'Brien, S.J. The occurrence and prevention of foodborne disease in vulnerable people. Foodborne Pathog. Dis. 2011, 8, 961-973. [CrossRef] [PubMed]

5. Hussain, M.A.; Dawson, C.O. Economic impact of food safety outbreaks on food businesses. Foods 2013, 2, 585-589. [CrossRef]

6. Bintsis, T. Foodborne pathogens. AIMS Microbiol. 2017, 3, 529-563. [CrossRef]

7. Bennett, S.D.; Sodha, S.V.; Ayers, T.L.; Lynch, M.F.; Gould, L.H.; Tauxe, R.V. Produce-associated foodborne disease outbreaks, USA, 1998-2013. Epidemiol. Infect. 2018, 146, 1397-1406. [CrossRef]

8. United States Department of Health and Human Services and United States Department of Agriculture. Dietary Guidelines for Americans 2015-2020. 2015. Available online: http://health.gov/dietaryguidelines/2015/guidelines/ (accessed on 3 November 2021).

9. Stevens, K.A.; Jaykus, L.A. Bacterial separation and concentration from complex sample matrices: A review. Crit. Rev. Microbiol. 2004, 30, 7-24. [CrossRef]

10. U.S. Food and Drug Administration. Bacteriological Analytical Manual (BAM). 2021. Available online: https://www.fda.gov/ food/laboratory-methods-food/bacteriological-analytical-manual-bam (accessed on 4 October 2021).

11. Kim, J.-H.; Oh, S.-W. Pretreatment methods for nucleic acid-based rapid detection of pathogens in food: A review. Food Control 2021, 121, 107575. [CrossRef]

12. Huang, F.; Zhang, Y.; Lin, J.; Liu, Y. Biosensors coupled with signal amplification technology for the detection of pathogenic bacteria: A review. Biosensors 2021, 11, 190. [CrossRef]

13. Ali, A.A.; Altemimi, A.B.; Alhelfi, N.; Ibrahim, S.A. Application of Biosensors for Detection of Pathogenic Food Bacteria: A Review Biosensors 2020, 10, 58. [CrossRef]

14. Lim, M.-C.; Park, J.Y.; Park, K.; Ok, G.; Jang, H.-J.; Choi, S.-W. An automated system for separation and concentration of food-borne pathogens using immunomagnetic separation. Food Control 2016, 73, 1541-1547. [CrossRef]

15. Thomas, M.C.; Shields, M.J.; Hahn, K.R.; Janzen, T.W.; Goji, N.; Amoako, K.K. Evaluation of DNA extraction methods for Bacillus anthracis spores isolated from spiked food samples. J. Appl. Microbiol. 2013, 115, 156-162. [CrossRef] [PubMed]

16. Seinige, D.; von Köckritz-Blickwede, M.; Krischek, C.; Klein, G.; Kehrenberg, C. Influencing factors and applicability of the viability Ema-qpcr for a detection and quantification of Campylobacter cells from water samples. PLoS ONE 2014, 9, e113812. [CrossRef] [PubMed]

17. Choi, Y.; Lee, H.; Lee, S.; Kim, S.; Lee, J.; Ha, J.; Oh, H.; Yoon, Y. Comparison of Upgraded Methods for Detecting Pathogenic Escherichia coli in Foods Using Centrifugation or Filtration. Korean J. Food Sci. Anim. Resour. 2017, 37, 799-803. [CrossRef] [PubMed]

18. Wang, R.; Xu, Y.; Liu, H.; Peng, J.; Irudayaraj, J.; Cui, F. An integrated microsystem with dielectrophoresis enrichment and impedance detection for detection of Escherichia coli. Biomed. Microdevices 2017, 19, 1-10. [CrossRef] [PubMed]

19. Wei, J.L.; Huang, D.Y.; Chen, Y.C. Using gadolinium ions as affinity probes to selectively enrich and magnetically isolate bacteria from complex samples. Anal. Chim. Acta 2020, 1113, 18-25. [CrossRef] [PubMed]

20. Chen, C.-T.; Reddy, P.M.; Ma, Y.-R.; Ho, Y.-P. Mass spectrometric identification of pathogens in foods using a zirconium hydroxide immobilization approach. Int. J. Mass Spectrom. 2012, 312, 45-52. [CrossRef]

21. Triplett, O.A.; Xuan, J.; Foley, S.; Nayak, R.; Tolleson, W.H. Immunomagnetic Capture of Big Six Shiga Toxin-Producing Escherichia coli Strains in Apple Juice with Detection by Multiplex Real-Time PCR Eliminates Interference from the Food Matrix. J. Food Prot. 2019, 82, 1512-1523. [CrossRef]

22. Diouani, M.; Sayhi, M.; Djafar, Z.; Ben Jomaa, S.; Belgacem, K.; Gharbi, H.; Ghita, M.; Popescu, L.-M.; Piticescu, R.; Laouini, D. Magnetic separation and centri-chronoamperometric detection of foodborne bacteria using antibiotic-coated metallic nanoparticles. Biosensors 2021, 11, 205. [CrossRef]

23. Briceno, R.K.; Sergent, S.R.; Benites, S.M.; Alocilja, E.C. Nanoparticle-Based Biosensing Assay for Universally Accessible Low-Cost TB Detection with Comparable Sensitivity as Culture. Diagnostics 2019, 9, 222. [CrossRef]

24. Matta, L.L.; Alocilja, E.C. Carbohydrate Ligands on Magnetic Nanoparticles for Centrifuge-Free Extraction of Pathogenic Contaminants in Pasteurized Milk. J. Food Prot. 2018, 81, 1941-1949. [CrossRef] [PubMed]

25. Stinson, L.F.; Ma, J.; Rea, A.; Dymock, M.; Geddes, D.T. Centrifugation does not remove bacteria from the fat fraction of human milk. Sci. Rep. 2021, 11, 1-8. [CrossRef]

26. Lindqvist, R. Preparation of PCR samples from food by a rapid and simple centrifugation technique evaluated by detection of Escherichia coli 0157:H7. Int. J. Food Microbiol. 1997, 37, 73-82. [CrossRef]

27. Zhou, C.; Wang, J.; Li, R.; Ye, K. High-throughput sequencing analysis of the bacterial community for assessing the differences in extraction methods of bacteria separation from chilled pork. LWT 2020, 134, 110213. [CrossRef] 
28. Wolffs, P.F.G.; Glencross, K.; Thibaudeau, R.; Griffiths, M.W. Direct quantitation and detection of salmonellae in biological samples without enrichment, using two-step filtration and real-time PCR. Appl. Environ. Microbiol. 2006, 72, 896-3900. [CrossRef] [PubMed]

29. Barre, L.; Brasseur, E.; Doux, C.; Lombard, B.; Besse, N.G. Sensitive enumeration of Listeria monocytogenes and other Listeria species in various naturally contaminated matrices using a membrane filtration method. Food Microbiol. 2015, 48, 171-177. [CrossRef]

30. Dwivedi, H.P.; Jaykus, L.-A. Detection of pathogens in foods: The current state-of-the-art and future directions. Crit. Rev. Microbiol. 2011, 37, 40-63. [CrossRef]

31. Kennedy, J.F.; Barker, S.A.; Humphreys, J.D. Microbial cells living immobilised on metal hydroxides. Nature 1976, 261, $242-244$. [CrossRef]

32. Yang, L. A Review of Multifunctions of Dielectrophoresis in Biosensors and Biochips for Bacteria Detection. Anal. Lett. 2012, 45, 187-201. [CrossRef]

33. Hanson, C.; Barney, J.T.; Bishop, M.M.; Vargis, E. Simultaneous isolation and label-free identification of bacteria using contactless dielectrophoresis and Raman spectroscopy. Electrophoresis 2019, 40, 1446-1456. [CrossRef]

34. Choi, W.; Min, Y.W.; Lee, K.Y.; Jun, S.; Lee, H.G. Dielectrophoresis-based microwire biosensor for rapid detection of Escherichia coli K-12 in ground beef. LWT 2020, 132, 109230. [CrossRef]

35. Bhusal, N.; Shrestha, S.; Pote, N.; Alocilja, E.C. Nanoparticle-based biosensing of tuberculosis, an affordable and practical alternative to current methods. Biosensors 2019, 9, 1. [CrossRef] [PubMed]

36. Castelló, J.; Gallardo, M.; Busquets, M.A.; Estelrich, J. Chitosan (or alginate)-coated iron oxide nanoparticles: A comparative study. Physicochem. Eng. Asp. 2015, 468, 151-158. [CrossRef]

37. Ways, T.M.M.; Lau, W.M.; Khutoryanskiy, V.V. Chitosan and its derivatives for application in mucoadhesive drug delivery systems. Polymers 2018, 10, 267. [CrossRef] [PubMed]

38. Matta, L.L.; Harrison, J.; Deol, G.S.; Alocilja, E.C. Carbohydrate-Functionalized Nanobiosensor for Rapid Extraction of Pathogenic Bacteria Directly from Complex Liquids with Quick Detection Using Cyclic Voltammetry. IEEE Trans. Nanotechnol. 2018, 17, 1006-1013. [CrossRef]

39. You, S.-M.; Jeong, K.-B.; Luo, K.; Park, J.-S.; Park, J.-W.; Kim, Y.-R. Paper-based colorimetric detection of pathogenic bacteria in food through magnetic separation and enzyme-mediated signal amplification on paper disc. Anal. Chim. Acta 2021, 1151, 338252. [CrossRef]

40. Benoit, P.W.; Donahue, D.W. Methods for Rapid Separation and Concentration of Bacteria in Food that Bypass Time-Consuming Cultural Enrichment. J. Food Prot. 2003, 66, 1935-1948. Available online: http:/ / meridian.allenpress.com/jfp/article-pdf/66/10/ 1935/1675695/0362-028x-66_10_1935.pdf (accessed on 15 June 2021). [CrossRef]

41. Matta, L.L. Biosensing Total Bacterial Load in Liquid Matrices to Improve Food Supply Chain Safety Using CarbohydrateFunctionalized Magnetic Nanoparticles for Cell Capture and Gold Nanoparticles for Signaling. Ph.D. Dissertation, Biosystems Engineering, Michigan State University, East Lansing, MI, USA, 2018. Available online: https:/ / www-proquest-com.proxy1.cl.msu. edu/pqdtglobal/docview/2160987664/fulltextPDF/FA5C0BF3C28B4FC4PQ/1?accountid=12598 (accessed on 13 October 2021).

42. El-Boubbou, K.; Gruden, C.; Huang, X. Magnetic Glyco-nanoparticles: A Unique Tool for Rapid Pathogen Detection, Decontamination, and Strain Differentiation. J. Am. Chem. Soc. 2007, 129, 52. [CrossRef]

43. Wang, Z.; Cai, R.; Gao, Z.; Yuan, Y.; Yue, T. Immunomagnetic separation: An effective pretreatment technology for isolation and enrichment in food microorganisms detection. Compr. Rev. Food Sci. Food Saf. 2020, 19, 802-3824. [CrossRef]

44. Kyeong, S.; Kim, J.; Chang, H.; Lee, S.H.; Son, B.S.; Lee, J.H.; Rho, W.-Y.; Pham, X.-H.; Jun, B.-H. Magnetic Nanoparticles. Adv. Exp. Med. Biol. 2021, 1309, 191-215. [CrossRef]

45. Augustine, R.; Abraham, A.R.; Kalarikkal, N.; Thomas, S. Novel Approaches of Nanotechnology in Food; Academic Press: Cambridge, MA, USA, 2016; Volume 1, pp. 271-312. [CrossRef]

46. Akbarzadeh, A.; Samiei, M.; Davaran, S. Magnetic nanoparticles: Preparation, physical properties, and applications in biomedicine. Nanoscale Res. Lett. 2012, 7, 1-13. [CrossRef] [PubMed]

47. Lohcharoenkal, W.; Abbas, Z.; Rojanasakul, Y. Advances in nanotechnology-based biosensing of immunoregulatory cytokines. Biosensors 2021, 11, 364. [CrossRef] [PubMed]

48. Tartaj, P.; Morales, M.P.; González-Carreño, T.; Veintemillas-Verdaguer, S.; Serna, C.J. Advances in magnetic nanoparticles for biotechnology applications. J. Magn. Magn. Mater. 2005, 290-291, 28-34. [CrossRef]

49. Ramanaviciene, A.; Popov, A.; Baliunaite, E.; Brasiunas, B.; Kausaite-Minkstimiene, A.; Tamer, U.; Kirdaite, G.; Bernotiene, E.; Mobasheri, A. Magneto-Immunoassay for the Detection and Quantification of Human Growth Hormone. Biosensors 2022, 12, 65. [CrossRef]

50. Khosroshahi, M.E.; Ghazanfari, L. Synthesis and functionalization of $\mathrm{SiO}_{2}$ coated $\mathrm{Fe}_{3} \mathrm{O}_{4}$ nanoparticles with amine groups based on self-assembly. Mater. Sci. Eng. C 2012, 32, 1043-1049. [CrossRef]

51. Cardoso, V.F.; Francesko, A.; Ribeiro, C.; Bañobre-López, M.; Martins, P.; Lanceros-Mendez, S. Advances in Magnetic Nanoparticles for Biomedical Applications. Adv. Healthc. Mater. 2018, 7, 1700845. [CrossRef]

52. Bilal, M.; Zhao, Y.; Rasheed, T.; Iqbal, H.M.N. Magnetic nanoparticles as versatile carriers for enzymes immobilization: A review. Int. J. Biol. Macromol. 2018, 120, 2530-2544. [CrossRef] 
53. Matta, L.L.; Alocilja, E.C. Emerging nano-biosensing with suspended MNP microbial extraction and EANP labeling. Biosens. Bioelectron. 2018, 117, 781-793. [CrossRef]

54. Lu, A.-H.; Salabas, E.L.; Schüth, F. Magnetic Nanoparticles: Synthesis, Protection, Functionalization, and Application Angew. Chemie Int. Ed. 2007, 46, 1222-1244. [CrossRef]

55. Pryazhnikov, D.V.; Kubrakova, I.V. Surface-Modified Magnetic Nanoscale Materials: Preparation and Study of Their Structure, Composition, and Properties. J. Anal. Chem. 2021, 76, 685-706. [CrossRef]

56. Chen, C.-T.; Yu, J.-W.; Ho, Y.-P. Identification of bacteria in juice/lettuce using magnetic nanoparticles and selected reaction monitoring mass spectrometry. J. Food Drug Anal. 2018, 27, 575-584. [CrossRef] [PubMed]

57. Lee, N.; Choi, S.-W.; Chang, H.-J.; Chun, H.S. Rapid Detection of Escherichia coli O157:H7 in Fresh Lettuce Based on Localized Surface Plasmon Resonance Combined with Immunomagnetic Separation. J. Food Prot. 2018, 81, 713-718. [CrossRef] [PubMed]

58. Vinayaka, A.C.; Ngo, T.A.; Kant, K.; Engelsmann, P.; Dave, V.P.; Shahbazi, M.-A.; Wolff, A.; Bang, D.D. Rapid detection of Salmonella enterica in food samples by a novel approach with combination of sample concentration and direct PCR. Biosens. Bioelectron. 2019, 129, 224-230. [CrossRef] [PubMed]

59. Wei, S.; Park, B.-J.; Kim, S.-H.; Seo, K.-H.; Jin, Y.-G.; Oh, D.-H. Detection of Listeria monocytogenes using Dynabeads ${ }^{\circledR}$ anti-Listeria combined with real-time PCR in soybean sprouts. LWT 2018, 99, 533-539. [CrossRef]

60. Yosief, H.O.; Weiss, A.A.; Iyer, S.S. Capture of Uropathogenic E. coli by Using Synthetic Glycan Ligands Specific for the Pap-Pilus. ChemBioChem 2013, 14, 251-259. [CrossRef] [PubMed]

61. Ghazzal, M.N.; Goffin, J.; Gaigneaux, E.M.; Nizet, Y. Magnetic nanoparticle with high efficiency for bacteria and yeast extraction from contaminated liquid media. J. Taiwan Inst. Chem. Eng. 2017, 71, 62-68. [CrossRef]

62. Chen, W.-J.; Tsai, P.-J.; Chen, Y.-C. Functional Nanoparticle-Based Proteomic Strategies for Characterization of Pathogenic Bacteria. Anal. Chem. 2008, 80, 9612-9621. [CrossRef]

63. Kveton, F.; Blsakova, A.; Kasak, P.; Tkac, J. Glycan Nanobiosensors. Nanomaterials 2020, 10, 1406. [CrossRef]

64. Pera, N.P.; Pieters, R.J. Towards bacterial adhesion-based therapeutics and detection methods. Medchemcomm 2014, 5, 1027-1035. [CrossRef]

65. Park, S.; Kim, G.-H.; Park, S.-H.; Pai, J.; Rathwell, D.; Park, J.-Y.; Kang, Y.-S.; Shin, I. Probing Cell-Surface Carbohydrate Binding Proteins with Dual-Modal Glycan-Conjugated Nanoparticles. J. Am. Chem. Soc. 2015, 137, 5961-5968. [CrossRef]

66. Campanero-Rhodes, M.A.; Palma, A.S.; Menéndez, M.; Solís, D. Microarray Strategies for Exploring Bacterial Surface Glycans and Their Interactions with Glycan-Binding Proteins. Front. Microbiol. 2020, 10, 2909. [CrossRef] [PubMed]

67. Uribe, E.; Steele, T.J.; Richards, R.C.; Ewart, K.V. Ligand and pathogen specificity of the Atlantic salmon serum C-type lectin. Biochim. Biophys. Acta-Gen. Subj. 2013, 1830, 2129-2138. [CrossRef] [PubMed]

68. Broeker, N.K.; Andres, D.; Kang, Y.; Gohlke, U.; Schmidt, A.; Kunstmann, S.; Santer, M.; Barbirz, S. Complex carbohydrate recognition by proteins: Fundamental insights from bacteriophage cell adhesion systems. Perspect. Sci. 2017, 11, 45-52. [CrossRef]

69. Harden, V.P.; Harris, J.O. The isoelectric point of bacterial cells. J. Bacteriol. 1953, 65, 198-202. [CrossRef]

70. Bayer, M.E.; Sloyer, J.L., Jr. The electrophoretic mobility of Gram-negative and Gram-positive bacteria: An electrokinetic analysis. Microbiology 1990, 136, 867-874. [CrossRef]

71. Silhavy, T.J.; Kahne, D.; Walker, S. The Bacterial Cell Envelope. Cold Spring Harb. Perspect. Biol. 2010, 2, a000414. [CrossRef]

72. Cohen, M. Notable aspects of glycan-protein interactions. Biomolecules 2015, 5, 2056-2072. [CrossRef]

73. Floyd, K.A.; Eberly, A.R.; Hadjifrangiskou, M. Adhesion of Bacteria to Surfaces and Biofilm Formation on MEDICAL Devices; Elsevier Ltd.: Amsterdam, The Netherlands, 2017.

74. Sarti, F.; Bernkop-Schnürch, A. Chitosan and thiolated chitosan. Adv. Polym. Sci. 2011, 243, 93-110. [CrossRef]

75. Rodrigues, N.F.M.; Neto, S.Y.; Luz, R.d.S.; Damos, F.S.; Yamanaka, H. Ultrasensitive Determination of Malathion Using Acetylcholinesterase Immobilized on Chitosan-Functionalized Magnetic Iron Nanoparticles. Biosensors 2018, 8, 16. [CrossRef]

76. Fratila, R.M.; Moros, M.; de la Fuente, J.M. Recent advances in biosensing using magnetic glyconanoparticles. Anal. Bioanal. Chem. 2016, 408, 1783-1803. [CrossRef]

77. Sommer, R.; Hauck, D.; Varrot, A.; Wagner, S.; Audfray, A.; Prestel, A.; Möller, H.M.; Imberty, A.; Titz, A. Cinnamide Derivatives of d-Mannose as Inhibitors of the Bacterial Virulence Factor LecB from Pseudomonas aeruginosa. ChemistryOpen 2015, 4, 756-767. [CrossRef]

78. Wiseman, M.E.; Frank, C.W. Antibody Adsorption and Orientation on Hydrophobic Surfaces. Langmuir 2012, 28, 1765-1774 [CrossRef] [PubMed]

79. Sinha, N.; Mohan, S.; Lipschultz, C.A.; Smith-Gill, S.J. Differences in Electrostatic Properties at Antibody-Antigen Binding Sites: Implications for Specificity and Cross-Reactivity. Biophys. J. 2002, 83, 2946-2968. [CrossRef]

80. Bhunia, A.K. Biosensors and Bio-Based Methods for the Separation and Detection of Foodborne Pathogens. Adv. Food Nutr. Res. 2008, 54, 1-44. [CrossRef] [PubMed]

81. Hyeon, J.-Y.; Deng, X. Rapid detection of Salmonella in raw chicken breast using real-time PCR combined with immunomagnetic separation and whole genome amplification. Food Microbiol. 2016, 63, 111-116. [CrossRef]

82. Wang, L.; Xue, L.; Guo, R.; Zheng, L.; Wang, S.; Yao, L.; Huo, X.; Liu, N.; Liao, M.; Li, Y.; et al. Combining impedance biosensor with immunomagnetic separation for rapid screening of Salmonella in poultry supply chains. Poult. Sci. 2020, 99, 1606-1614. [CrossRef] 
83. Li, Q.; Zhang, S.; Cai, Y.; Yang, Y.; Hu, F.; Liu, X.; He, X. Rapid detection of Listeria monocytogenes using fluorescence immunochromatographic assay combined with immunomagnetic separation technique. Int. J. Food Sci. Technol. 2017, 52, 1559-1566. [CrossRef]

84. Chai, Z.; Bi, H. Capture and identification of bacteria from fish muscle based on immunomagnetic beads and MALDI-TOF MS. Food Chem. X 2022, 13, 100225. [CrossRef]

85. Bhandari, D.; Chen, F.C.; Bridgman, R.C. Detection of Salmonella Typhimurium in Romaine Lettuce Using a Surface Plasmon Resonance Biosensor. Biosensors 2019, 9, 94. [CrossRef]

86. Tokunaga, Y.; Wakabayashi, Y.; Yonogi, S.; Saito, M.; Yamaguchi, N. Microfluidic rapid quantification of Salmonella enterica serovar Typhimurium collected from chicken meat using immunomagnetic separation after formaldehyde treatment. Int. J. Food Sci. Technol. 2021, 56, 5402-5408. [CrossRef]

87. Quintela, I.A.; de los Reyes, B.G.; Lin, C.-S.; Wu, V.C.H. Simultaneous Colorimetric Detection of a Variety of Salmonella spp. in Food and Environmental Samples by Optical Biosensing Using Oligonucleotide-Gold Nanoparticles. Front. Microbiol. 2019, 10, 1138. [CrossRef] [PubMed]

88. Park, J.Y.; Park, K.; Ok, G.; Chang, H.-J.; Park, T.J.; Choi, S.-W.; Lim, M.-C. Detection of Escherichia coli O157:H7 Using Automated Immunomagnetic Separation and Enzyme-Based Colorimetric Assay. Sensors 2020, 20, 1395. [CrossRef] [PubMed] 